\title{
THE SPRINGBOK SIXTH DIVISION
}

\author{
by The Late Major Hertzog Biermann
}

The Springbok Sixth Division was a mighty armoured force Of men whose ancestors made war in ships, on foot and horse They wrote a stirring chapter in Springbok Martial lore When they went to sunny Italy in Nineteen-Forty-Four.

They were in the Springbok First Team and their modest claim to fame Was their response to the clarion call : "Pay up and play the game!" Their duty they did nobly as their fathers did of old They proudly wore the Sixth Div flash of Springbok green and gold.

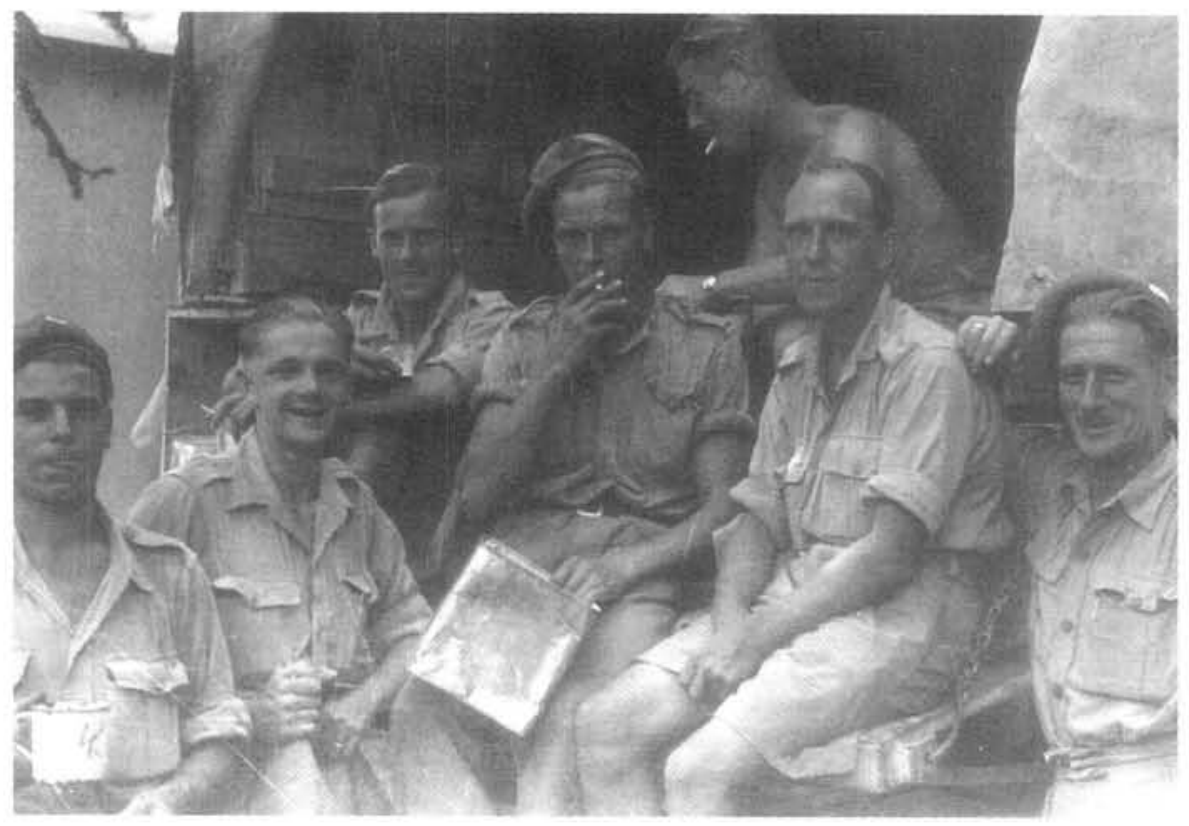

From grim Cassino's ruin to Salvaro's lofty head From May until December our men had fought and bled First dust, then rain and mud, then cold and slush and snow Then those long months in the Winter Line before they reached the Po

Behind them lay a storied trail from bleak Taranto's shore And all the way up Italy they learned new arts of war They drew first blood at Piglio and at Paliano

They went through Rome in hot pursuit, their sights set on the Arno.

Civita Castellana was their next port of call

The Springboks showed the enemy that they were on the ball On Lordly Mont' Sorrate they trained their guns and mortars But the bird had flown by the time they came to Kesselring's headquarters.

Through Vallerona and Viterbo to the stream with waters red The Sixth Division thundered on as the Allied host's spearhead The tankmen of the SSB made mincemeat of the foe In the first big battle fought on the field of Celeno.

In honour of the blooding of the Springbok armoured might The place was named PROTEA to commemorate the fight Then tanks and trucks and guns and jeeps churned up the powdered dust As General Poole directed the Sixth Div's northward thrust. 


\section{Bagnio Regio, Orvieto and Allerona fell}

Then came the rain and the mud they were bogged down for a while Cetona was the next town they captured in their stride

But on Chiusi's terraced slopes our men were sorely tried.

The FC-CTH lost a company there

But soon enough the foe was routed from his vineyard lair Here many centuries ago, a boastful tyrant strodeLars Porsena of Clusium in the Horation ode!

"Oom Jannie" came to see his troops and brought a word of cheer

"Press on," he said "to victory, forget the setback here"

The Springboks got the message, their spirits full restored

Their motto: "Pass the ammo and praise be to the Lord!"

The towns and cities tumbled like ninepins in a row

Then came the Sixth Division to Castel di Brolio

The home of famed Chianti wine bade them a welcome quaff

Their thirst they quenched and on they went when they had enough.

At Radda some were lined up for inspection by King George

His visit was a tribute and did bonds of friendship forge

He reminded them that they were heirs of glorious Alamein

And Sixth Division proudly proclaimed the mountains from the plain.

It was a new kind of war, up their among the peaks

But the Springboks did in days what they feared would take them weeks

Querciavella and Michele, Fili and Domini

Were conquered as they raced to greet, the Rose of Italy.

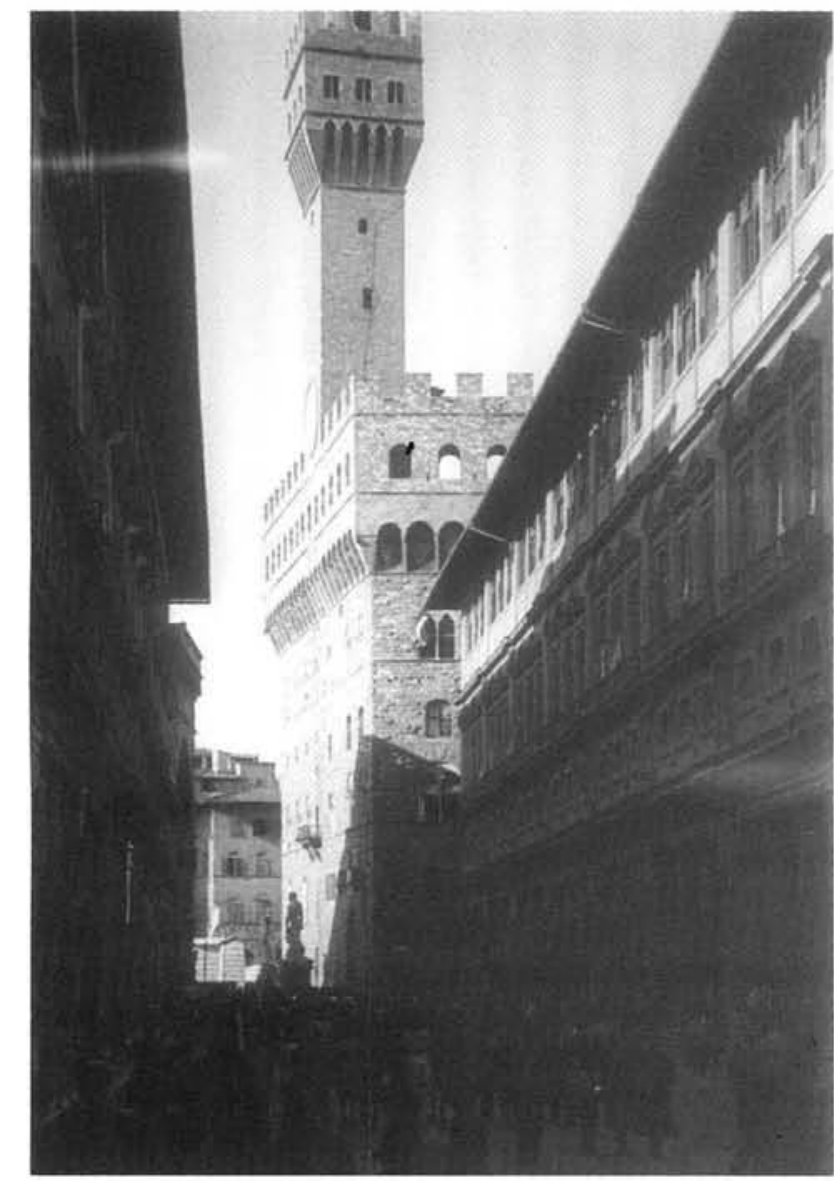

When Strada lay behind them and they tackled Impruneta

Poole said: "Next stop is Florence boys and we have to go to get there

Before Field Marshall Freyberg and his Kiwis win the race

To be the first in Florence, the home of art and grace."

It was on the Fourth of August in the first light of day

That the ILH-and-Kimberley boys swept through in bold foray

They reached the Arno River bank and following close behind

Came tankmen, sappers, gunners by the townsfolk cheered and wined.

From the villas of the affluent and abodes of mean estate

The liberated people flocked to the city's Roman Gate

They came to cheer the victors with kiss and cup and bloom

They recognised the auguries that spelt the foreman's doom. 
The bridges over the river were blown in the dark of night Those who were there will not forget that grim and awesome sight While Paratroops Division with stubborn Prussian pride Gave battle from the North Bank to stem the thundering tide.

Fair Florence was divided between two sets of foes They shelled and mortared daily but seldom came to blows Until the Germans pulled out and fell back on the slopes Of the mighty Appenine barrier on which they set their hopes.

Then soon we first encountered a new and fearsome thing A nine-barrelled Nebelwerfer that a song of death did sing Some called it the "Five O'clock Whistle" which marked the break of day And others, "Moaning Minnie", as its bombs whined our way.

When the Springboks crossed the Arno and the mountains loomed ahead To Pistoia and to Prato the armoured pursuit sped Then followed gory clashes "midst verdant beech and pine Where the 16th SS cohorts stood in Hitler's Gothic Line.

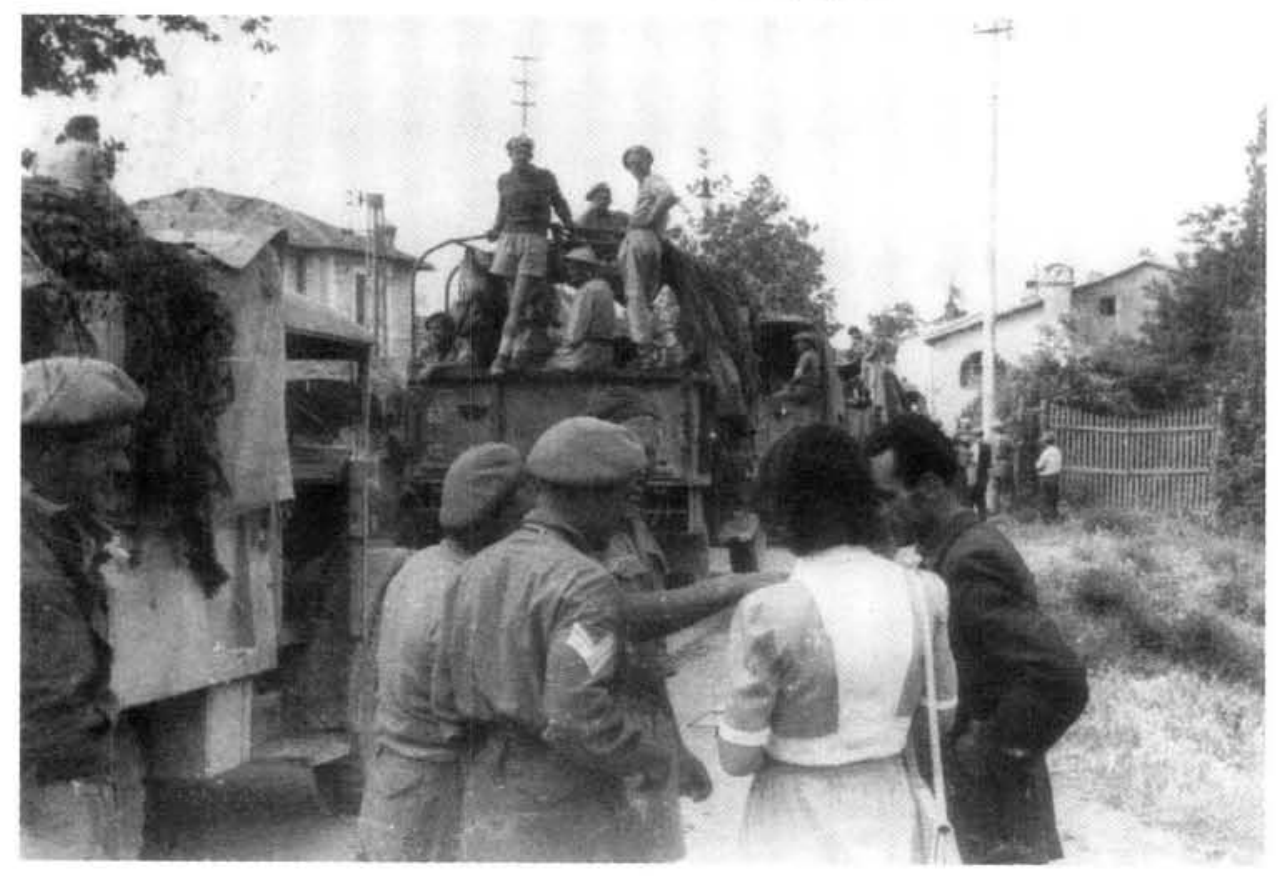

On the highroad to Bologna the Springboks forged ahead Into the mountain fastness that formed the watershed They took Castiglione but they did not then know That it would take full seven months to break through to the Po.

The rain came down in torrents on the peaks and fissured vales The tanks and trucks were bogged down an a score of mud-filled trails Thenceforth the Sixth Div's battles on the roof of Italy Were fought by Biermanns's Gunners and Palmers's Infantry.

It was a fearsome prospect that faced the 12th Brigade

From peak to peak in front of them the message was relayed

By the Reichsfuehrer Division, the SS corps d'elite

"The elements are with us, we have the Springboks beat."

To the East of Mont'Visese, the ILH-KIM R Fought valiantly but vainly, to cross the mountain bar Then came the fateful order to Comrie's Carbineers To wrest the highest Apennine peak from the Panzer Grenadiers. 
It was gallant Peter Francis who led his company

Through swirling mist and lashing rain to gain the victory

The company of Germans who lay in wait up there

Could not believe that such a feat their enemy would dare.

The First Company of the First Battalion, Panzer Grenadiers

Was routed in that dawn assault by the RN Carbineers.

Many were killed and wounded and they captured a score and ten

But not a single one was lost of the Carbineers bold men.

It was a different story on Stanco's shell-pocked slope

Where the Carbineers were driven back by stormtroops crazed with dope

They formed up at Grizzana and came in mess array

It was a fearsome sight to see on that chill Autumn day.

The FC-CTH and the Wits and De la Rey

Went through to take the mountain upon the following day

The battleground was churned up by tons of Springbok Shells

And the German troops retreated to more mountain peaks and fells.

Through the village of Grizzana where the walls were stained with blood

The Carbineers marched onward up to their knees in mud

They fought for Monte Pezza and wiped out Stanco's stain

As the sun shone on the battle field after days of pouring rain.

Point 806 was taken by the Wits and De La Rey

And the ILH-KIM R came through to bring the foe to bay

On the last stretch of mountain mass crowned by Point 826

Where the SS Div was flung from high across it's River Styx.

On the right flanks of the Springbok's against the foe arrayed

Marched the gallant three battalions of the British Guards Brigade

Scots, Grenadiers and Coldstreamers who wore the Sixth Div flash

And Pretoria's Regiment of tanks shared in their famed dash.

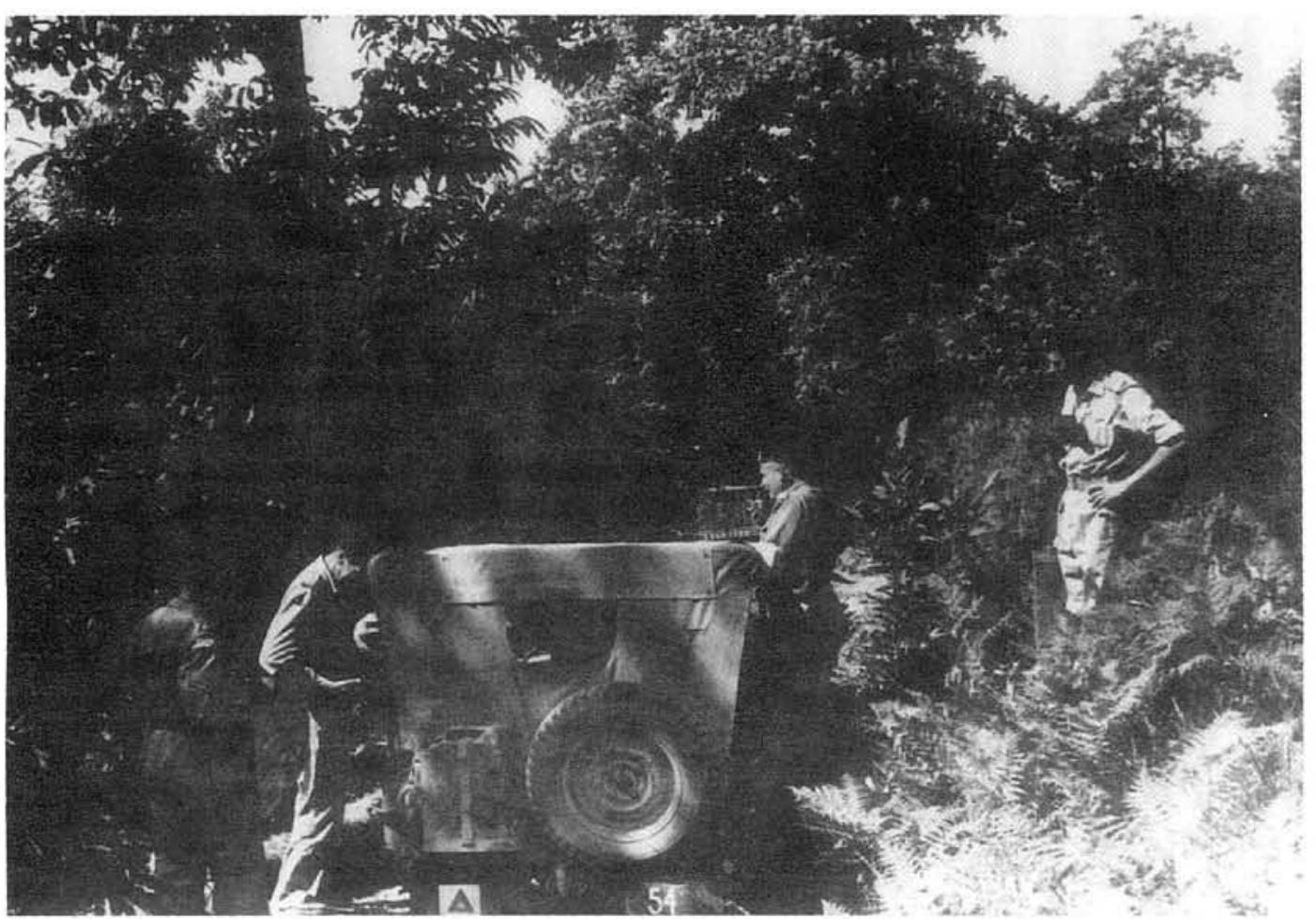


The Carbineers relieved the Scots on Monte Termine

While their brother regiment slay high above the Reno valley

Durban's Royal Regiment with Vickers guns and mortars

Dug themselves in with all of these in the role of close supporters.

The lot of the front-line soldier was not all shot and shell

The enemy propaganda gave him some joy as well

On the nightly radio broadcast came that well-loved refrain

- Sung by Milan's "Three Doves of Peace” - of sweet Lili Marlene.

The first snow fell in Christmas week in Nineteen-Forty Four

And the Springboks had to suit themselves - in white - to a brand new kind of war They patrolled the ice-bound no-man's land across its length and breadth

Where the wintry air was laden with the sour-sweet stench of death.

Between the Sixth Div front line and the German rock-bound lair Lay a sinister stretch of no-man's land of human life stripped bare When farming folk were massacred by vengeful SS bands

After Partisans revolted to free their mountain lands.

In many a lonely hamlet and farmsteads round about Lay bodies of those innocents who died in the fatal rout Old men, women and children slain by their brutal foe Before God's hand enveloped them in a shroud of driven snow.

The outpost at Point 512 was manned by Carbineers And many a story still is told when they talk of bygone years Of curious things that happened around that ghostly Shrine On the path to San Martino in the German Winter Line

Another RNC outpost was down below Salvaro

Where the ground slopes gently down to the banks of the River Reno That was where Norman Clothier, the SA Legion's head Was succoured by "Koffie" Reznek when he was all but dead.

Before the winter ended the Sixth Div went to rest

At Lucca whence they marched again when they were full refreshed Back up into the mountains on Route Six Two O When only Sole stood between them and the mighty River Po.

With Hitler on the run up North the peace was coming fast For Hitler's Army of the South the fatal die was cast They faced us in those mountains defiant to the last But the knell of doom was sounded when the guns began to blast.

Field Marshall Alexander arrayed the Allied host Of 28 Division spread abreast from coast to coast The British 8th, and the US 5th, were told to drive the foe From his eyrie in the mountains and down across the Po.

The line-up of the Allies was culled from far and wide There were Britons, Yanks, Canadians and Springboks in the side A Jap-American combat team and a Brigade of Jews Brazilians and Poles and folk of other hues.

A new Brigade - the 13th - came into being when The British Guards were sent off to parts beyond our ken In command was "Happy Jack" Bester, ex-Wits-De la Rey And he was told, when Sole fell, to Bologna lead the way.

So Sixth Div had an Armoured and two Infantry Brigades Artillery, Sappers, Signallers and troops of other grades 
When the SAAF and the US Air Force came to bomb and strafe the foe As Mark Clark gave the order to break out to the Po.

In front lay Monte Sole with Caprara on the left. Beyond lay Mont' Abelle above the mountain cleft The Springbok Sixth Division was ready for the drive On the fifteenth day of April in Nineteen-Forty Five.

It was the last big battle for the South Africans to fight They had to climb those mountains in the middle of the night The FC-CTH and the Wits-De la Rey Had to be on top by sunrise on that stark, historic day.

Our bombers and fighters came to terrorise the foe The mountain were plastered by the gunners down below But at the zero hour the boys on foot stood still With bayoneted rifles to go in for the kill.

On the slopes below Caprara the Wits-De la Rey Were mortared on the start-line as they squared up for the day But led by dauntless Van der Riet they upward toiled that night To win a hard-fought battle before the day was light.

The final Charge on Sole was led by a brave young man A Rhodesian named Mollet who through a minefield ran With his FC-CTH platoon to rout the stubborn foe And his reward was a well-deserved DSO.

On the morrow of that triumph a tragedy befell When the Fates for Angus Duncan, tolled their fatal bell The Colonel went to visit his boys up in the line When upon the mountain pathway, he trod upon a mine.

The battle was'nt over before the sun went down It raged on unabated for Mont' Abelle's crown Uncounted deeds of valour were done by night and day Before the Sixth Division could secure the right of way.

The Carbineers were sent off with the Armour close at hand The Germans fled and left the line named Genghis Khan unmanned They broke through to Bologna with the Yanks in line abreast The Germans headed for the Po flushed from their Appenine nest.

The SSB and PAG went pounding after Fritz And up in front to lead them was the dauntless "Papa" Britz At Finale nell Emiglia the verdant plains of storied Lombardy A million men surrendered to Alexander's host And the thunder of guns was stilled from coast to coast.

It was a famous victory and soon the war was done And we could go back to our homes beneath the Southern sun It was a martial triumph that earned a laurel crown But not for Mussolini : they hanged him upside down.

In Berlin Hitler followed him and died a death of shame And neither left to history aught, but a dishonoured name On V-Day there in Europe it was great to be alive After our last big battle in Nineteen-Forty Five. 